\title{
Creep gantry quay and accounting environment in its reconstruction
}

\author{
Vladimir Korovkin \\ St. Petersburg State Polytechnical University, 195251, St. Petersburg, Russian Federation
}

\begin{abstract}
Abstruct. Quay gantry type calculates in the technical literature in the form of a frame with hard rigel and rigid stopping up of piles. To account for long-term durability of the structures in the plastic clay soils in the existing scheme is additionally used the equation of state of a Newtonian viscous fluid. In its uses the coefficient of shear viscosity.

The author used the proposed of the early engineering universal method of calculating berthing quays with respect to the thin walls, secured of anchor piles. In the design scheme not used lower secured racks, and counts up the stiffness characteristics of the soil, clarifying the nature of the work structures.

The author proposed a generalized mechanical model of compressible porous clay environment with the structural element. To account for the operation of facilities in the plastic clay soils in the proposed scheme uses a different equation of state of a Newtonian viscous fluid. It uses the ratio of the coefficient of viscosity in compression of porous soil (coefficient of Trutona).This allows us to consider how long-term strength and displacement of the structure in time.
\end{abstract}

Considers the issues of contamination and turbidity in the reconstruction of the gantry bulwark

Keywords: pile quay, hard grillage, a generalized model of creeping soil, a compressible viscous fluid.

\section{INTRODUCTION}

The quays of St. Petersburg are of practical interest in the construction and reconstruction of the existing finishes of banks of rivers and canals in the form of a thin retaining wall with inclined anchor piles (gantry quay). It is during the construction does not require large volumes of earthworks that reduces harmful impact on the environment. This is especially valuable in dense areas of the city. The problem of providing long-term durability of thin retaining walls on deformable in time grounds received a special urgency. Such designs are widespread, but they are characterized by high sensitivity to deformation of soils.

Normative documentation on this type of embankment does not account for instant and longterm deformation characteristics of the Foundation soil. Clarification of the calculation municipal mooring quays gantry type and reduction of adverse environmental impact during construction is an important issue.

\section{PURPOSE OF THE WORK}

Ensure long-term strength of the port hydraulic structures on deform in time basis, typical of St. Petersburg is of practical interest. Existing calculations of such structures using the hydrodynamic model of steady flow of a viscous incompressible fluid Navier-Stokes (N. N. Maslov, A.
I. Budin, V. P. Karpov). This allowed them to assess the long-term strength of some types of port facilities. However, the above model describes the steady-state creep of slopes and slopes composed of clayey soils (N. M. Maslov, 1977). The operating experience of retaining walls of the creeping grounds showed that better fits the model of unsteady flow of a viscous compressible fluid. Since creep of the mooring is of a dying character in time.

The objective of this paper is to implement engineering method of calculation of wharfage waterworks on creeping of the ground. The porous foundation soil is describes by the model of a viscous compressible fluid, which. describing the decaying creep. Further dealt with environmental issues on the example of the reconstruction of the mooring quay in St. Petersburg.

\section{LITERATURE REVIEW}

In the existing technical literature $[1,2,3]$ and regulations $[4,5]$ each type of port hydraulic structures has its own method of calculation. Translation of manual calculation on the PC significantly reduced the computational complexity of the work, but not fully used large automation capabilities. Because, most of the methods of calculation based on the terms and assumptions used in the era before computers. This requires additional verification of the calculation results due to a wide 
range of interval values of the original data, as well as in cases of the adoption of rigid sealing the bottom of the pile in the soil $[6,7,8]$.

To simplify the understanding of the mechanism of interaction of structural elements with the soil and maximize the use of the computer by the author in 2002 was proposed universal engineering calculation method, which can be applied to any design of the mooring quay [9] and expanded in [10, 11].

Calculation of piled embankments grillage type has a significant number of works by Russian and foreign scientists. First N. M. Gersevanov was given general solution to the problem of calculation of pile grillage with the rigid rigel. He considering these structures as absolutely rigid frame with beams on elastic supportsstilts with hard of the sealing (1913). The work of recent years, , as a rule, use of the classical calculation scheme $[12,13]$. Note the works of foreign scientists dedicated to the calculation of piled embankments grillage type [14-17].

Thin retaining wall, of anchored structures inclined piles, in the estimated attitude is a frame system with rigid beams and flexible racks. It is a special case of a design scheme N. M. Gersevanov. Departmental method of calculation is given in the work [18].

Work noted above describe the calculation of pile structures in soils do not possess of creep. They are used as a baseline, when the variable properties of the soil in time. Weak and clay foundation of soil have rheological properties. They exhibit properties of creep and relaxation. These soils are changing their stress-strain state in time. Rheological properties of soils were studied by S. S. Vyalov, Y. K. Zaretsky, G. A. Geniev, S. R. Meschyan, R. Reiner, Z. G. TerStepanyan, V. A. Florin, L. Shukle, A. Bishop, K. Roscoe, A. Scepton and others.

N. N. Maslov (1968) used the model of a viscous liquid to account for the interaction of the retaining structures with creeping grounds. A. J. Budin taked into account the change in time of the reactive pressure of the foundation soil at a quay wall [13]. He used the model of steady flow of a viscous incompressible fluid for the description of the foundation soil. This solution is a particular case of changes in stress with time in a restrained retaining wall, excluding instant and long-term deformation characteristics of the foundation soil. A similar model for calculating thin quay wall was used Karpov V. M. (1977).

Review of current status of the problem shows that in the technical literature and in the regulations for the calculation of structures grillage type is used metod of N. M. Gersevanov. This scheme is used as basis in the calculation of buildings for long lasting durability. Creep of the foundation soil is described by the model of steady-state motion of a viscous incompressible fluid. Without deformation of this method in determining immediate and long-term strength distorts the design scheme of the building. This introduces some error in the determination of the forces in the elements of design and not gives the calculation for the second limit state.

\section{THE SOLUTION OF THIS PROBLEM}

Elasticity, plasticity is a characteristic property of solids, the viscosity of the liquid. Many real materials have both these properties. Viscous behavior of clayey soils is described by the following theories: the theory of linear viscoelastic deformation; the theory of hereditary creep; the creep theory; the kinetic theory of strength and creep of soils; mathematical models viscoplastic behavior of soils. All described creep theory allow to obtain a more or less satisfactory agreement with the test data. However, the choice of a particular theory in relation to the problems of soil mechanics is determined primarily by the requirements of the task.

Viscous behavior of clayey soils is described a generalized model of the behavior of creeping soil. Existing models of creeping soil in the port hydraulic engineering take into account the shear stress causing shear viscous steady flow. The author adopted the viscous porous medium. She resists compression under normal stresses. This model describes damped amounts creep in the shore facilities on clay foundation soil. Generalized model of creeping soil have structural element $\mathrm{S}\left(\mathrm{I}_{1}\right)$ environment and combines of models Kelvin - Voigt and Maxwell (Fig. 1a) [19]. The elastic properties of the bodies are indicated by the symbol N, and the viscous symbol N. (Fig.1a). Structural element of $\mathrm{S}\left(\mathrm{I}_{1}\right)$ depends on the ball tensor. It takes into account the change of the deformation modulus $\mathrm{E}$ and coefficient of viscosity $\eta \mathrm{c}$ from the immersion depth of the wall. The viscous properties of the bodies designated by the model in the form of a cylinder filled with a viscous compressible porous medium, in which is immersed a perforated piston, and the speed dip is described by Newton's law.

$$
\sigma=\eta_{\mathrm{c}} \dot{\delta}
$$

where $\eta_{c}-$ the coefficient of viscosity in compression (coefficient of Trutona); $\delta-$ speed compression (tension). (Fig.1a Graphs of creep and relaxation in relation to the clay-court basis of clay soils depending on the depth $\mathrm{h}$ is shown in Fig. 1b. The deformation of the viscoelastic body develops in time, but is damped (Fig. 1b, top). After unloading deformation is fully recovered in time. Wednesday shows the properties of relaxation (Fig. 1b, bottom). The relationship between normal stress and the longitudinal deformation is described by a variable E (Fig. 1c).

The analogy between the deformation diagrams for solids and viscous fluids allows the use of solutions of the elasticity theory and the theory of plasticity for tasks in a viscous fluid. These solutions are used by simply replacing the strain on its speed. 


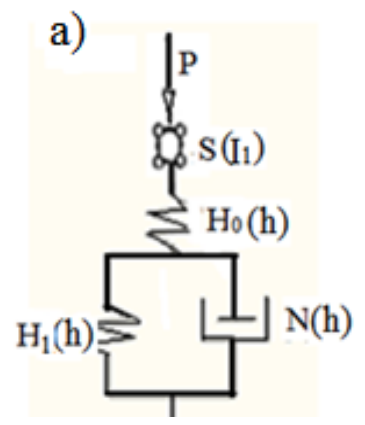

b)
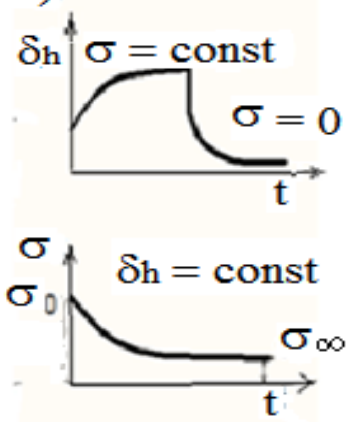

c)

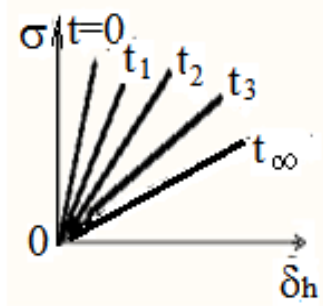

Fig. 1. a) Generalized mechanical model of compressible porous clay environment with the proposed structural element $S\left(I_{1}\right)$. b) Graphs of creep (top) and relaxation (bottom) with additional consideration $\mathrm{h}$. c) The variable values of the deformation modulus of the soil over time.

Fig. 1. a) Mechanical model of a compressible porous clay environment. b) Graphs of creep (top) and relaxation (bottom). c) The variable values of the deformation modulus of the soil in time.

At constant characteristics $\mathrm{E}$ and $\mathrm{y}_{\mathrm{c}}$ deformation of damped creep quay wall in time is:

$$
\Delta_{\text {п }}=\Delta_{0}+\left(\Delta_{\infty}-\Delta_{0}\right) \exp a\left(\mathrm{t} / \mathrm{t}_{\text {п ст }}\right),
$$

where $\Delta_{0}=\Delta^{*}\left(\mathrm{~h}_{0} / \mathrm{h}\right)^{2}$ - the initial deformation of the wall $\left(\Delta^{*}-\right.$ limit displacement of the bottom wall with a minimum depth $\mathrm{h}_{0}$ [20], $\mathrm{h}$ is the actual depth of the wall; $\Delta \infty=\Delta_{\infty} *\left(\mathrm{~h}_{0} / \mathrm{h}\right)^{2}$ - stable deformation of the wall. It is defined similarly to work [20], in view of the module of the compressive strain $(\mathrm{E} \infty ; a-$ correction coefficient; $t, t_{п \text { ст }}-$ current and a finite time creep.

The period of damped creep (time delay deformations) is simply equal to:

$$
\mathrm{t}_{\text {п ст }}=\mathrm{y}_{\mathrm{c}} / \mathrm{E}_{\infty},
$$

where $y_{c}=3 \eta-$ linear coefficient of viscosity grip (friction force at compression of the area at unit velocity gradient), approximately is defined via the ratio of shear viscosity $\mathrm{n} ; \mathrm{E}_{\infty}$ - long module of the compressive strain are determined by the test stamps. $\mathrm{E} \infty$ is approximately equal to:

$$
\mathrm{E}_{\infty}=(0,3 \div 0,8) \mathrm{E},
$$

where of more importance to the solid clays, respectively less - of weak clays, intermediate values consistency are accepted by interpolation. Deformation properties of the coefficient similarly accepted due to the proportionality of the $\mathrm{K}_{\mathrm{P}}$ and $\mathrm{E}$.

Example. The initial mixture of top of wall height of $7 \mathrm{~m}$ [18] of order $\Delta 0=11 \mathrm{~mm}$ was obtained with the use of the solution [9]. Taking into account dependence (2) at $a=3.0$ get $\Delta_{\infty}=89,1 \mathrm{~mm}$.

The nature of the curvature of a curve "a" is better described by a equation of the type:

$$
\Delta \mathrm{t}=\Delta_{0}+\Delta_{\infty}\left(\mathrm{t} / \mathrm{t}_{\text {п ст }}\right)^{1 / 4}
$$

Estimated value of the total displacement of faltering creep is $100,1 \mathrm{~mm}$.

The offset of the top designs for the observation period for a period of 6 years (A. J. Budin, 1971) reached $94 \mathrm{~mm}$. The starting offset in the application of external loads was only $17 \mathrm{~mm}$

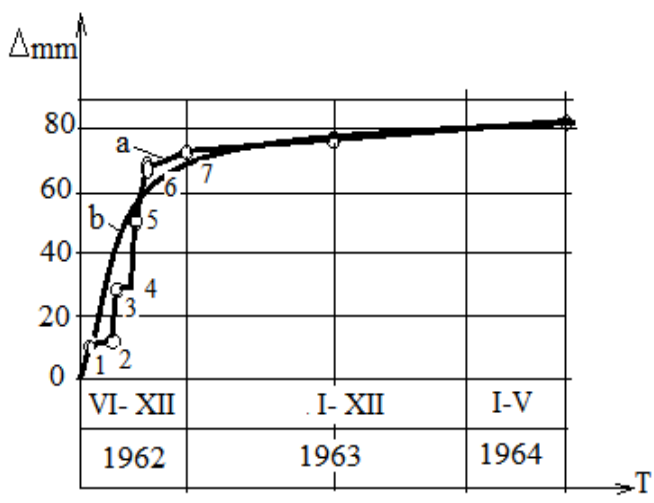

Fig. 2. The curves compare the cordon line mooring quay St. Petersburg river port. (a) Experimental broken curve corresponds to different degrees of loading of the wall. b) Calculated curve.

\section{$\mathrm{V}$ ENVIRONMENTAL SAFETY DURING RECONSTRUCTION OF THE EMBANKMENT}

The reconstruction of includes dredging described promenade. The amount of dredging was 10.5 thousand $\mathrm{m}^{3}$ of soil on the area of $5200 \mathrm{~m}^{2}$. When dredging and the dumping of excavated soil, calculation of zones of turbidity for the reservoir was carried out in accordance with the work of [21]. 
Assessment of contamination of soil. Before dredging was determined class of contamination of soils in accordance with the recommendations of the regional standard [22].

TABLE 1

POLLUTION SEIZED SOILS IN COMPARISON WITH THE PERMISSIBLE LEVELS

\begin{tabular}{|l|c|c|c|c|}
\hline $\begin{array}{l}\text { The name } \\
\text { of the } \\
\text { substance }\end{array}$ & $\begin{array}{l}\text { Concentration, } \\
\mathrm{mg} / \mathrm{kg}\end{array}$ & $\begin{array}{l}\text { Target } \\
\text { level, } \\
\mathrm{mg} / \mathrm{kg}\end{array}$ & $\begin{array}{l}\text { Maximum } \\
\text { level (check } \\
\text { level), } \\
\mathrm{mg} / \mathrm{kg}\end{array}$ & $\begin{array}{l}\text { Class } \\
\text { pollution } \\
\text { seized } \\
\text { soils }\end{array}$ \\
\hline $\begin{array}{l}\text { Cadmium } \\
(\mathrm{Cd})\end{array}$ & - & 0.8 & 2 & 0 class \\
\hline $\begin{array}{l}\text { Chromium } \\
(\mathrm{Cr})\end{array}$ & 45 & 100 & 380 & 0 class \\
\hline $\begin{array}{l}\text { Copper } \\
(\mathrm{Cu})\end{array}$ & 60 & 35 & $35(90)$ & II class \\
\hline Lead $(\mathrm{Pb})$ & 52 & 85 & 530 & 0 class \\
\hline $\begin{array}{l}\text { Mercury } \\
(\mathrm{Hg})\end{array}$ & 0.25 & 0.30 & 0.5 & 0 class \\
\hline $\begin{array}{l}\text { Nickel } \\
(\mathrm{Ni})\end{array}$ & 42 & 35 & $35(45)$ & II class \\
\hline Zinc $(\mathrm{Zn})$ & 92 & 140 & 480 & 0 class \\
\hline $\begin{array}{l}\text { Arsenic } \\
(\text { As) }\end{array}$ & - & 29 & 55 & 0 class \\
\hline
\end{tabular}

The surface layer of bottom sediments is slightly contaminated (table 1). In accordance with the Regional norm [22] the soils in the area where dredging may be used without restriction for the blade into water bodies, education areas.

The calculation of turbidity during dredging. Spot turbidity during dredging is determined by the speed of sedimentation $\mathrm{V}_{\mathrm{oc}}$ and the consumption of soil $\mathrm{q}$, transformed into a balanced state [21]. Effective sedimentation rate of suspension is equal to:

$$
V_{o c}=\frac{\sum_{i=1}^{n} V_{o c i} \cdot p_{i}}{p}=0,15 \mathrm{~cm} / \mathrm{c}
$$

where $\mathrm{n}$ is the number of selected fractions of the soil size less than $0.1 \mathrm{~mm}$; Voc - hydraulic coarseness of individual $\mathrm{n}$-fractions of particles, $\mathrm{cm} / \mathrm{s}$ (tab. 2 ); PI weight content in the soil of the individual $n$-fractions of particles smaller than $0.1 \mathrm{~mm}$ fraction (table. ); $\mathrm{p}$ is the total content by weight of soil particles smaller than $0.1 \mathrm{~mm}$, in fractions of a unit.

The flow rate of the soil q, transformed into suspended state is equal to:

$$
q=p \cdot k \cdot Q \cdot \gamma_{T} \cdot \frac{\gamma-\gamma_{B}}{\lambda_{T}-\gamma_{B}}=0,0015 \mathrm{~m} / c
$$

where $\mathrm{p}$ is the total content by weight of soil particles smaller than $0.1 \mathrm{~mm}$ fraction; $\mathrm{k}=0.05$ to the transition rate of the soil in suspension, in fractions of a unit; $\mathrm{Q}$ $=96 \mathrm{~m}^{3} /$ hour - performance technical means on the ground; $\gamma=1.7 \mathrm{t} / \mathrm{m}^{3}$ volumetric weight of the soil in natural addition; $\gamma_{B}=1 \mathrm{t} / \mathrm{m}^{3}$ volumetric weight of water, $\mathrm{t} / \mathrm{m}^{3} ; \gamma_{\mathrm{T}}=2.4 \mathrm{t} / \mathrm{m}^{3}$ volumetric weight of soil particles, $\mathrm{t} / \mathrm{m}^{3}$.

TABLE 2

GRANULOMETRIC COMPOSITION OF SOILS DREDGING

\begin{tabular}{|l|l|l|}
\hline $\begin{array}{l}\text { The particle size, } \\
\mathrm{mm}\end{array}$ & $\begin{array}{l}\text { Weight content, } \\
\%\end{array}$ & $\begin{array}{l}\text { Hydraulic particle size } \\
\text { of suspended solids } \\
\text { Voc, cm/s }\end{array}$ \\
\hline 0.001 & 5.1 & 0.000059 \\
\hline 0.005 & 10.2 & 0.00148 \\
\hline 0.010 & 9.8 & 0.00593 \\
\hline 0.015 & 8.2 & 0.0133 \\
\hline 0.02 & 7.3 & 0.0235 \\
\hline 0.03 & 7.2 & 0.0525 \\
\hline 0.04 & 8.5 & 0.0923 \\
\hline 0.05 & 6.2 & 0.1426 \\
\hline 0.06 & 7.1 & 0.203 \\
\hline 0.07 & 7.3 & 0.272 \\
\hline 0.08 & 6.7 & 0.35 \\
\hline 0.09 & 6.2 & 0.437 \\
\hline 0.1 & 5.9 & 0.53 \\
\hline & &
\end{tabular}

TABLE 3

POSSIBLE CONSEQUENCES OF EDUCATION SPOTS TURBIDITY DURING DREDGING

\begin{tabular}{|l|l|l|l|l|l|}
\hline $\begin{array}{l}\text { Seizures } \\
\text { of soil, } \\
\mathrm{m}^{3}\end{array}$ & $\begin{array}{l}\text { PDK } \\
\text { suspended } \\
\text { solids, } \\
\mathrm{mg} / \mathrm{dm} 3\end{array}$ & $\begin{array}{l}\text { Catego- } \\
\text { ry } \\
\text { logopo- } \\
\text { lis }\end{array}$ & $\begin{array}{l}\text { Area of the } \\
\text { dull- } \\
\text { making } \\
\text { from the } \\
\text { concentrati } \\
\text { on was less } \\
\text { than the } \\
\text { PDK, } \mathrm{m}^{2}\end{array}$ & $\begin{array}{l}\text { Current of } \\
\text { guy stains } \\
\text { with a } \\
\text { concentratio } \\
\text { n less than } \\
\text { the PDK, } \\
\text { hour }\end{array}$ & $\begin{array}{l}\text { Distance } \\
\text { that the spot } \\
\text { can go with } \\
\text { the flow, } \\
\text { km }\end{array}$ \\
\hline 18000 & 0.25 & II & 300000 & 6.1 & 8.8 \\
\hline 18000 & 0.75 & II & 250000 & 5.5 & 7.9 \\
\hline
\end{tabular}

Payment for environmental damage of suspended solids received in the waters during the period of dredging in volume $588,6 \mathrm{~m} 3$ amounted $43947 \mathrm{rb}$. The calculation was performed Xia in accordance with the Order of Rostechnadzor from 05.04.2007 No. 204 and the resolution of the Government of the Russian Federation dated 12.06.2003, No. 344.

\section{CONCLUSIONS}

1. Pile quay gantry type calculates in the technical literature in the form of a frame with hard grillage and rigid restraint piles. To account for long-term durability of structures in the plastic clay soils in the existing scheme is additionally used the equation of state of a Newtonian viscous fluid. Idem uses the coefficient of shear viscosity. Model stationary viscous flow does not take account of the decaying creep in the shore facilities.

2. The author proposed a generalized mechanical model with a structural element, which allows to take into account creep and relaxation of the foundation soil due to the depth of immersion of the wall. 
3. Calculation of the thin walls in the initial period of time used a job [9]. In a design model are introduced deformation characteristics of the soil, to clarify the nature of work facilities.

4. To account for the rheological properties, the author used the model of a compressible Newtonian viscous fluid. Idem was used a coefficient of the coefficient of viscosity in compression of discrete soil (coefficient of Trutona). This allows us to consider how long durability and damped displacement of the structure in

5. Considered are the issues of pollution and turbidity in the reconstruction of the gantry bulwark

\section{REFERENCES}

[1] G.N. Smirnov, V.V. Aristarkhov, S.N. Levichev, A.G. Sidorov E.A. Korchaginю. Ports and port facilities. Ed. DIA, Moscow, 2003, 463 p.

[2] P.I. Yakovlev, A.P Tyurin, Y.A. Portucel. Port hydraulic structures. Ed. Transport, Moscow, 1990, 320 p

[3] P.P. Kulmach, V.P. Filippenok, N.G. Zaritovskiy. Marine hydraulic structures. Ch. II, Mooring, offshore and shore protection structures. LVVISU, Leningrad, 1991, $391 \mathrm{p}$.

[4] Design of the mooring quays, CH-RF 54.1-85, MRF RSFSR, Moscow, 1991, $247 \mathrm{p}$.

[5] Instruction on designing marine berthing and shore protection structures. RD 31.31.55.93 RD 31.31.55.93, MMF, Moscow, 1996.

[6] PLAXIS. Plaxis v. 8.2 , Finite Element Code for soil and rock analyses. Netherlands, 2002.

[7] Program GEO5 for design and analysis of retaining armagrandi and gravitational structures Certificate of conformity No ROSS CZ.SP.N, Moscow, 2012.

[8] Program Cluster, version 1, Engineering and consulting centre for Foundation. Moscow. to the hydraulic port facilities. Advanced Materials Research, Vols. 945-949, 2005, pp. 541548.
[9] V.S. Korovkin. Universal method of calculating berthing quays The first scientific-practical conference Sea and river ports of Russia, Moscow, 2002, 103-105 pp.

[10] T. Dang, V. Korovkin. Engineering kinematic theory of ground contact pressure in the annex to the hydraulic port facilities. Advanced Materials Research, Vols. 945-949, 2014, pp. 541548.

[11], A. Melentev, V. Korovkin. Calculation of Retaining Walls with Anchoring at Different Levels Applied Mechanics and Materials, 725-726, 2015, pp. 185-189.

[12] V.V. Znamensky. Engineering calculation method for horizontally loaded group of piles. Ed. DIA, Moscow, 2000, $128 \mathrm{p}$.

[13] A.Y. Budin. City and harbour quays Ed. Polytechnic, St. Petersburg, 2014, $418 \mathrm{p}$

[14] CUR-publication 166. Damwand constructies | ISBN 90376 0638 | CUR, Gouda, the Netherlands, 4th issue, 2005.

[15] Grabe J. Sheet Piling Handbook Design. Thyssen Krupp GfT, Bautechnik GmbH HSP HOESCH. Spundwand and Profil GmbH, Hamburg, 2008.

[16] Design Manua. 1. Steel Sheet Piling United States, Steel Updated and reprinted by U. S. Department of Transportation. FHWA with permission, 1984.

[17] A Handbook of Quay Walls. CUR Centre for Civil Engineering Research, Havenbedrijf Rotterdam NV, Gemeentewerken Rotterdam. Published by Taylor \& Francis, the Netherlands ISBN: 978-0-415-36439-3, 2005.

[18] Guidelines for the design of the mooring quays, Part VI, Embankment reinforced concrete pile with inclined ankerwyke piles, AK 2070, Lengiprorechtrans, Leningrad, 1970, 32 p.

[19] S. Vialov. Reological principles of soil mechanics. Ed. Higher Scools. Moscow, 1978, 447p

[20] A. I. Alimento, V. A. Pogodin, S. V. Korovkin, Yu. Fomin, I. V. Lisowski, K. N. Shines. Waterworks sea ports. SPb., Ed. "LAN", 2014, $440 \mathrm{~S}$.

[21] Guidelines for calculating the propagation zones of turbidity during dredging and dumping in the waters of MO Navy (WRDS 12-05-03), Moscow, 2003, p. 87.

[22] Standards and criteria for the assessment of contamination of bottom sediments. Regional normative St. Petersburg, 1996. 